research

\title{
ANGPTL6 expression is coupled with mitochondrial OXPHOS function to regulate adipose FGF21
}

\author{
Seul Gi Kang1,2,*, Hyon-Seung Yi1,*, Min Jeong Choi1,2,*, Min Jeong Ryu3, \\ Saetbyel Jung', Hyo Kyun Chung', Joon Young Chang',2, Yong Kyung Kim', \\ Seong Eun Lee 1,2, Hyeon-Woo Kim 1,2, Hoil Choi4, Dong Seok Kim, Ju Hee Lee', \\ Koon Soon Kim', Hyun Jin Kim', Chul-Ho Lee ${ }^{5}$, Yuichi Oike ${ }^{6}$ and Minho Shong' \\ ${ }^{1}$ Research Center for Endocrine and Metabolic Diseases, Chungnam National University School of \\ Medicine, Daejeon, Korea \\ 2Department of Medical Science, Chungnam National University School of Medicine, Daejeon, Korea \\ 3Department of Biochemistry, Chungnam National University School of Medicine, Daejeon, Korea \\ 4Peptron, Inc., Daejeon, Korea \\ ${ }^{5}$ Animal Model Center, Korea Research Institute of Bioscience and Biotechnology, Daejeon, Korea \\ ${ }^{6}$ Department of Molecular Genetics, Graduate School of Medical Sciences, Kumamoto University, \\ Chuo-ku, Kumamoto, Japan \\ *(S G Kang, H-S Yi and M J Choi contributed equally to this work)
}

Correspondence should be addressed to M Shong

Email

minhos@cnu.ac.kr

\begin{abstract}
Recent studies revealed that the inhibition of mitochondrial oxidative phosphorylation (OXPHOS) is coupled with the mitochondrial unfolded protein response, thereby stimulating the secretion of non-cell autonomous factors, which may control systemic energy metabolism and longevity. However, the nature and roles of noncell autonomous factors induced in adipose tissue in response to reduced OXPHOS function remain to be clarified in mammals. CR6-interacting factor 1 (CRIF1) is an essential mitoribosomal protein for the intramitochondrial production of mtDNAencoded OXPHOS subunits. Deficiency of CRIF1 impairs the proper formation of the OXPHOS complex, resulting in reduced function. To determine which secretory factors are induced in response to reduced mitochondrial OXPHOS function, we analyzed gene expression datasets in Crif1-depleted mouse embryonic fibroblasts. Crif1 deficiency preferentially increased the expression of angiopoietin-like 6 (Angpt/6) and did not affect other members of the ANGPTL family. Moreover, treatment with mitochondrial OXPHOS inhibitors increased the expression of Angpt/6 in cultured adipocytes. To confirm Angpt/6 induction in vivo, we generated a murine model of reduced mitochondrial OXPHOS function using adipose tissue-specific Crif1-deficient mice and verified the upregulation of Angpt/6 and fibroblast growth factor 21 (Fgf21) in white adipose tissue. Treatment with recombinant ANGPTL6 protein increased oxygen consumption and Ppar $\alpha$ expression through the extracellular signal-regulated kinase/ mitogen-activated protein kinase pathway in cultured adipocytes. Furthermore, the ANGPTL6-mediated increase in Ppar $\alpha$ expression resulted in increased FGF21 expression, thereby promoting $\beta$-oxidation. In conclusion, mitochondrial OXPHOS function governs the expression of ANGPTL6, which is an essential factor for FGF21 production in adipose tissue and cultured adipocytes.
\end{abstract}

Journal of Endocrinology (2017) 233, 105-118
() 2017 Society for Endocrinology Printed in Great Britain
Published by Bioscientifica Ltd 


\section{Introduction}

Mitochondrial oxidative phosphorylation (OXPHOS) function plays an essential role in energy metabolism in adipose tissue. The expression of OXPHOS genes in adipose tissue was significantly decreased in diet-induced obese and $d b / d b$ mice compared to that in control mice (Wilson-Fritch et al. 2004, Rong et al. 2007). These findings suggest that OXPHOS function in adipose tissue plays an important role in the regulation of systemic and local homeostasis of energy metabolism, defects in which are implicated as causes of hepatic steatosis, insulin resistance and type 2 diabetes. The mitochondrial DNA copy number is decreased by aging and increasing body mass index and is also positively associated with insulinstimulated lipogenesis in human white adipose tissue (Kaaman et al. 2007). The depletion of mitochondrial transcription factor $\mathrm{A}$ in the adipose tissue, which is necessary for mtDNA stability and transcription, paradoxically increases mitochondrial oxidation, thereby protecting mice against obesity and insulin resistance (Vernochet et al. 2012). A recent series of studies revealed that impaired OXPHOS function can increase lifespan in Drosophila melanogaster, Caenorhabditis elegans and mice (Dillin et al. 2002, Liu et al. 2005, Copeland et al. 2009). Furthermore, increased longevity resulting from reduced mitochondrial function in key tissues was mediated by a non-cell-autonomous secreted signaling factor, which was suggested to be a mitokine in C. elegans (Durieux et al. 2011). However, the induction of secreted factors as a result of reduced mitochondrial OXPHOS function has not been fully established in mammals.

Fibroblast growth factor 21 (FGF21) has long been studied as a critical metabolic regulator controlling glucose homeostasis and insulin sensitivity in metabolic tissues, including skeletal muscle, adipose tissue and hypothalamus (Hotta et al. 2009). Physiological secretion of FGF21 is mainly regulated by peroxisome proliferatoractivated receptor (PPAR) $\alpha$-driven expression, which is augmented in the fasting phase in liver (Inagaki et al. 2007). Recent studies revealed that FGF21 secretion by skeletal muscle is associated with mitochondrial OXPHOS impairment and stress, which activates the activating transcription factor 4 (ATF4)-mediated integrated stress response (Kim et al. 2013). However, the secreted factors whose expression is coupled with mitochondrial OXPHOS function in adipose tissue remain to be identified.

CR6-interacting factor 1 (CRIF1), also known as CR6/ GADD45-interacting protein, is a mitochondrial protein that is important for the insertion of intramitochondrial nascent OXPHOS polypeptides into the inner mitochondrial membrane (Kim et al. 2012). CRIF1 deficiency impairs proper formation of the OXPHOS complex because of aberrant synthesis of mitochondrial DNA-encoded OXPHOS polypeptides, resulting in severe OXPHOS dysfunction in vitro and in vivo (Kim et al. 2012). Therefore, conditional tissue-specific knockout of Crif1 may be a useful model to determine the mouse phenotypes generated by reduced mitochondrial OXPHOS function (Kim et al. 2012, 2015, Ryu et al. 2013, Byun et al. 2015).

In this study, we investigated the non-cell autonomous factors induced in association with reduced OXPHOS function, using Crif1-deficient cells and adipose tissue-specific Crif1-knockout (AdKO) mice and the effects of adipo-mitokines on the expression of adipose FGF21. Based on these observations, we propose that adipose mitokines may mediate the specific adipose adaptive stress response or play broader systemic roles, alone or with other mitokines or hormones.

\section{Materials and methods}

\section{Mice and ethical considerations}

Floxed Crif1 (Crif1flox/flox) mice were generated as described previously (Kwon et al. 2008). Adiponectin-Cre transgenic mice were provided by Dr Evan Rosen. Crif $1^{\text {flox/flox }}$ mice were bred with Adiponectin-Cre transgenic mice to generate adipocyte-specific Crif1-knockout mice. All mice were on a C57BL/ 6 background. All mice were maintained in a controlled environment (12-h light/12-h darkness cycle; humidity, 50-60\%; ambient temperature, $22 \pm 2^{\circ} \mathrm{C}$ ) and fed a normal chow diet in a specific pathogen-free animal facility at the Chungnam National University Hospital Preclinical Research Center. All animals received humane care according to institutional guidelines, and all experimental procedures were approved by the Institutional Review Board of Chungnam National University School of Medicine (Daejeon, South Korea).

\section{Generation of Crif1-deficient mouse embryonic fibroblasts (MEFs) and cell culture}

Mouse embryonic fibroblasts (MEFs) were isolated from trypsin/EDTA-digested E13.5 wild-type (WT) and (c) 2017 Society for Endocrinology Printed in Great Britain
Published by Bioscientifica Ltd 
Crif1-deficient embryos. SV40-large $\mathrm{T}$ antigen was transfected into MEFs for immortalization. Cells were cultured in Dulbecco's modified Eagle's medium (DMEM; Hyclone, Logan, UT, USA) supplemented with 10\% fetal bovine serum (Invitrogen) and 1\% penicillin/streptomycin (Gibco) in a humidified incubator with 5\% $\mathrm{CO}_{2}$. 3T3-L1 adipocytes (passage 5-6) obtained from ATCC were cultured with $10 \%$ newborn calf serum (Invitrogen) in DMEM. The cells were differentiated using 3-isobutyl-1-methylxanthine $(0.5 \mathrm{mM})$, dexamethasone $(1 \mu \mathrm{M})$, insulin $(10 \mu \mathrm{g} / \mathrm{mL})$ and 10\% fetal bovine serum. 3T3-L1 adipocytes, primary hepatocytes, C2C12 myoblasts and mature immortalized brown adipocytes were treated with recombinant angiopoietin-like 6 (ANGPTL6) protein (rANGPTL6, 200ng/ $\mathrm{mL})$ or the OXPHOS complex inhibitors oligomycin $(2 \mu \mathrm{g} /$ $\mathrm{mL}$ ), carbonyl cyanide $m$-chlorophenylhydrazone (CCCP, $5 \mu \mathrm{M})$ and rotenone $(1 \mu \mathrm{M})$ for $12 \mathrm{~h}$.

\section{Isolation of adipocytes and stromal vascular cells (SVCs)}

Epididymal and inguinal adipose tissues were dissected in mice and minced into fine pieces using sterile scissors. Minced samples were placed in HEPES-buffered PBS supplemented with $10 \mathrm{mg} / \mathrm{mL}$ BSA (Sigma-Aldrich) and type 1 collagenase $(1 \mathrm{mg} / \mathrm{mL})$ at $37^{\circ} \mathrm{C}$ on an orbital shaker for $30 \mathrm{~min}$ and then centrifuged at $1000 \mathrm{~g}$ for $5 \mathrm{~min}$ at $4^{\circ} \mathrm{C}$ to pellet erythrocytes and other blood cells. Once digestion was complete, samples were passed through a sterile $70 \mu \mathrm{m}$ nylon mesh (BD Falcon; Franklin Lakes, NJ, USA). The suspension was centrifuged at $1000 \mathrm{~g}$ for $5 \mathrm{~min}$. The pelleted cells were collected as the stromal vascular cells (SVCs), and the floating cells were collected as the adipocyte-enriched fraction. SVCs were resuspended in red blood cell (RBC) lysis buffer and incubated at room temperature for $5 \mathrm{~min}$. The RBC-depleted SVCs were centrifuged at $500 \mathrm{~g}$ for $5 \mathrm{~min}$, and the pellet was frozen in liquid nitrogen.

\section{Isolation of primary hepatocytes}

As previously described (Yi et al. 2014), primary murine hepatocytes were isolated from mice using collagenase perfusion, followed by differential centrifugation on a Percoll (GE Healthcare) density gradient. Isolated cells were cultured in DMEM supplemented with 10\% fetal bovine serum (Invitrogen) and 1\% penicillin/ streptomycin (Invitrogen) at a density of $2 \times 10^{5}$ cells/well on 6-well plates.

\section{Western blot analysis}

3T3-L1 adipocytes, adipose tissue, liver and muscle from mice were lysed in RIPA buffer $(30 \mathrm{mmol} / \mathrm{L}$ Tris, $\mathrm{pH} 7.5,150 \mathrm{mmol} / \mathrm{L}$ sodium chloride, $1 \mathrm{mmol} / \mathrm{L}$ phenylmethylsulfonyl fluoride, $1 \mathrm{mmol} / \mathrm{L}$ sodium orthovanadate, 1\% Nonidet P-40, 10\% glycerol, containing phosphatase and protease inhibitors). Western blot analyses were performed with 30-50 $\mu \mathrm{g}$ protein from the tissue or cell homogenates using commercially available antibodies. Primary antibodies against OXPHOS complex subunits (NDUFA9, UQCRC2, and ATP5A1) were purchased from Invitrogen. AntiCOX4 (\#4844), anti-extracellular signal-regulated kinase (ERK) (\#3179) and anti-mitogen-activated protein kinase (MAPK) (\#9212) antibodies were purchased from Cell Signaling. Anti-CRIF1 (sc-134882) antibody was obtained from Santa Cruz Biotechnology. Anti- $\beta$-actin (A2228) and anti- $\alpha$-tubulin (T5168) antibodies were obtained from Sigma-Aldrich. Anti-ANGPTL6 (MAB7527) antibody was purchased from R\&D Systems. Anti-FGF21 antibody was obtained from Novus Biologicals (Littleton, CO, USA). Immunoreactive bands were visualized on polyvinylidene difluoride membranes using alkaline phosphate-linked anti-rabbit or anti-mouse antibody and an enhanced chemiluminescence detection system (LI-COR Biosciences; Lincoln, NE, USA).

\section{Enzyme-linked immunosorbent assay (ELISA)}

Blood was collected from the hearts of mice under general anesthesia. Samples were centrifuged at $18,500 \boldsymbol{g}$ for $3 \mathrm{~min}$, and the supernatants were collected. The measurement of ANGPTL6 (Cusabio Biotech, Wuhan, Hubei, China) or FGF21 (R\&D Systems) was performed in serum or protein lysates from adipose or liver tissues according to the manufacturer's instruction.

\section{Microarray analysis}

Total RNA was prepared from WT and Crif1-deficient MEFs. RNA amplification and labeling were performed using the Low RNA Input Linear Amplification kit PLUS (Agilent Technologies). Array hybridization and scanning were performed using a DNA microarray chip and scanner (Agilent Technologies). Array data were analyzed using Feature Extraction and GeneSpring Software (Agilent Technologies). 


\section{Real-time polymerase chain reaction (PCR)}

Total RNA was extracted from cells or tissues using TRIzol Reagent (Invitrogen) in accordance with the manufacturer's instructions. The same quantity of total RNA was reverse-transcribed into complementary DNA (cDNA) using M-MLV Reverse Transcriptase and oligo-dT primers (Invitrogen). Real-time polymerase chain reaction (PCR) was performed using cDNA, QuantiTect SYBR Green PCR Master Mix (QIAGEN) and the specific primers listed in Table 1 . The comparative Ct method was used to quantify transcripts, which were normalized to $\beta$-actin expression. Values were expressed as fold changes vs control groups.

\section{Measurement of oxygen consumption rate (OCR)}

The mitochondrial oxygen consumption rate (OCR) was measured using a Seahorse XF-24 extracellular flux analyzer (Seahorse Bioscience Inc., North Billerica,

Table 1 Primers used in real-time PCR (mouse).

\begin{tabular}{|c|c|c|}
\hline Genes & Forward $\left(5^{\prime}-3^{\prime}\right)$ & Reverse $\left(5^{\prime}-3^{\prime}\right)$ \\
\hline Angpt/1 & $\begin{array}{l}\text { GCTGGGAGGTAAC- } \\
\text { GAGATTCAG }\end{array}$ & $\begin{array}{l}\text { TGGGAGAAGTTGCCAGAT- } \\
\text { CAG }\end{array}$ \\
\hline Angpt/2 & $\begin{array}{l}\text { GATCCAGAGTGAC- } \\
\text { CAGAATC }\end{array}$ & TCTCAGGCTTCACCAGGTAG \\
\hline Angpt/3 & $\begin{array}{l}\text { AGCACCAAGAAC- } \\
\text { TACTCCCC }\end{array}$ & ATAAACGGCAGAGCAGTCGG \\
\hline Angpt/4 & $\begin{array}{l}\text { TCAAAGACTCCGAG- } \\
\text { GATAGA }\end{array}$ & AAAGCCCTTTTCGTAGTTTT \\
\hline Angptl6 & $\begin{array}{l}\text { ACTACGA- } \\
\text { CAGCTTCTCCTTG }\end{array}$ & AGTGCTGAAAGGTTTGTCAT \\
\hline Angpt/7 & $\begin{array}{l}\text { TGCTGTGAGGAGAT- } \\
\text { GAGGGA }\end{array}$ & TCCATCACCTGCATGACCAC \\
\hline Fgf21 & $\begin{array}{l}\text { AGATCAGGGAG- } \\
\text { GATGGAACA }\end{array}$ & TCAAAGTGAGGCGATCCATA \\
\hline Ppar & $\begin{array}{l}\text { AGAAGTTGCAG- } \\
\text { GAGGGGATT }\end{array}$ & TTGAAGGAGCTTTGGGAAGA \\
\hline Ppary & $\begin{array}{l}\text { ATCTTAACTGCCG- } \\
\text { GATCCAC }\end{array}$ & TGGTGATTTGTCCGTTGTCT \\
\hline $\begin{array}{l}\text { Acyl-CoA } \\
\text { oxidase }\end{array}$ & $\begin{array}{l}\text { ATGACCCCACTTCCT- } \\
\text { GACAC }\end{array}$ & GAAGGTCAGCCACCATGATT \\
\hline$H S L$ & $\begin{array}{l}\text { AGACACCAGCCAAC- } \\
\text { GGATAC }\end{array}$ & GCGGTTAGAAGCCACATAGC \\
\hline CD36 & $\begin{array}{l}\text { TGCTGGAGCTGT- } \\
\text { TATTGGTG }\end{array}$ & TGGGTTTTGCACATCAAAGA \\
\hline$U C P 2$ & $\begin{array}{l}\text { GATTGAAGGTCCCC- } \\
\text { GTTTCT }\end{array}$ & ACATCTGTGGCCTTGAAACC \\
\hline UCP3 & $\begin{array}{l}\text { TGCTGCTGACAC- } \\
\text { GAGAAACT }\end{array}$ & ATTTCCCATCAGGTCAGTGC \\
\hline$P G C 1 \alpha$ & $\begin{array}{l}\text { TCTCAGTA- } \\
\text { AGGGGCTGGTTG }\end{array}$ & $\begin{array}{l}\text { AGCAGCACACTCTATGT- } \\
\text { CACTC }\end{array}$ \\
\hline $18 s$ & $\begin{array}{l}\text { GTAACCCGTT- } \\
\text { GAACCCCATT }\end{array}$ & CCATCCAATCGGTAGTAGCG \\
\hline
\end{tabular}

MA, USA) in 24-well plates. On the day before OCR measurement, the sensor cartridge was placed into the calibration buffer supplied by Seahorse Bioscience and incubated at $37^{\circ} \mathrm{C}$ in a non- $\mathrm{CO}_{2}$-containing incubator. 3T3-L1 adipocytes and primary hepatocytes were cultured on Seahorse XF-24 plates at a density of 20,000 cells per well. The cells were washed and incubated with DMEM lacking sodium bicarbonate at $37^{\circ} \mathrm{C}$ in a non- $\mathrm{CO}_{2}$-containing incubator for $1 \mathrm{~h}$. The medium and mitochondrial OXPHOS inhibitors were adjusted to $\mathrm{pH} 7.4$ on the day of the OCR assay. The basal OCR was measured three times, and three readings were taken after the addition of each mitochondrial OXPHOS inhibitor, before the injection of subsequent inhibitors. Oligomycin $(2 \mu \mathrm{g} / \mathrm{mL})$ and rotenone $(1 \mu \mathrm{M})$ were used as the mitochondrial OXPHOS inhibitors. The basal and post-oligomycin OCRs were calculated by averaging the last three measurements after achieving a steady state. Coupled respiration was expressed as the percentage decrease from basal respiration. In addition, CCCP $(5 \mu \mathrm{M})$ was used to measure maximal mitochondrial respiration. OCR was automatically calculated and recorded by the sensor cartridge and Seahorse XF-24 software.

\section{Luciferase reporter assay}

To assess the PPAR $\alpha$ activity induced by ANGPTL6, 3T3-L1 adipocytes were transiently transfected with pGL3b-PPAR $\alpha$ Luc provided by Dr Kook Hwan Kim (Yonsei University College of Medicine, Korea) using Lipofectamine plus (Invitrogen) and OptiMEM (Invitrogen) for 24h. pGL3BFgf21(-2078/+129) and pGL3B-Fgf21(-1370/+129) vectors have been described (Kim et al. 2013). Cells were treated with rANGPTL6 protein (200 or $500 \mathrm{ng} / \mathrm{mL}$, ABNOVA, Taipei, Taiwan), fenofibrate ( $5 \mu \mathrm{M}$, PPAR $\alpha$ agonist; SigmaAldrich) and GW6471 (1 $1 \mathrm{M}$, PPAR $\alpha$ antagonist; SigmaAldrich) for $24 \mathrm{~h}$. Luciferase levels were determined using a luciferase assay kit (Promega). For each sample, luciferase activity was normalized to the protein concentration of whole cell lysates.

\section{Statistical analysis}

Data are presented as means \pm standard deviation (S.D.). To compare values obtained from two or more groups, Student's $t$-test or one-way analysis of variance was performed. A $P$ value less than 0.05 was considered statistically significant.

Published by Bioscientifica Ltd. 


\section{Results}

\section{Crif1 deficiency or impaired OXPHOS function increases ANGPTL6 expression}

We previously reported that CRIF1 is essential for the translation and expression of respiratory chain subunits (Kim et al. 2012). Loss of Crif1 function resulted in profound impairment of OXPHOS function and was accompanied by reduced expression of mtDNA-encoded respiratory subunits (Kim et al. 2012, 2015, Ryu et al. 2013). To identify the signaling factors whose expression may be coupled with reduced mitochondrial OXPHOS function, we compared gene expression datasets in Crif1-deficient and WT MEFs. The genes related to inflammatory response,
A

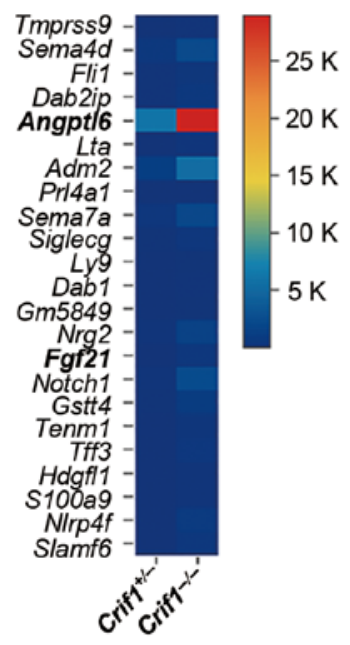

D

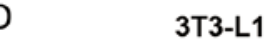

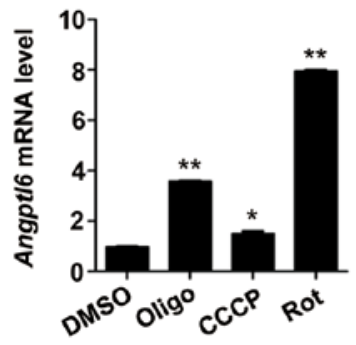

C2C12

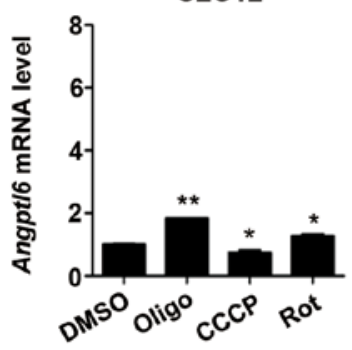

B

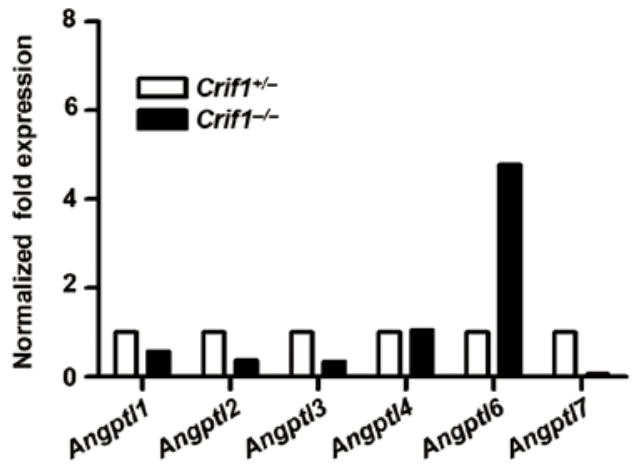

C

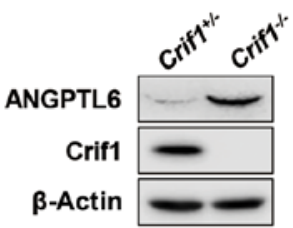

Brown adipocytes
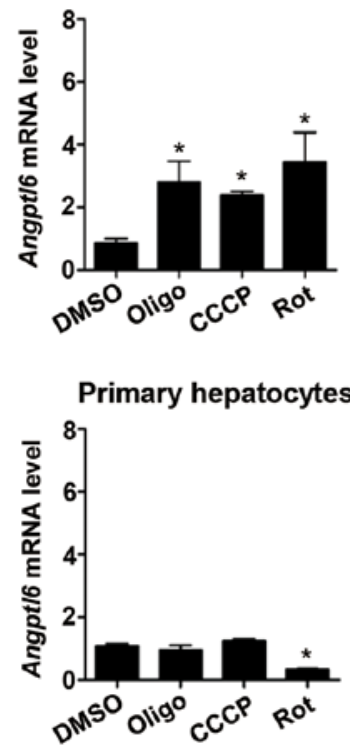
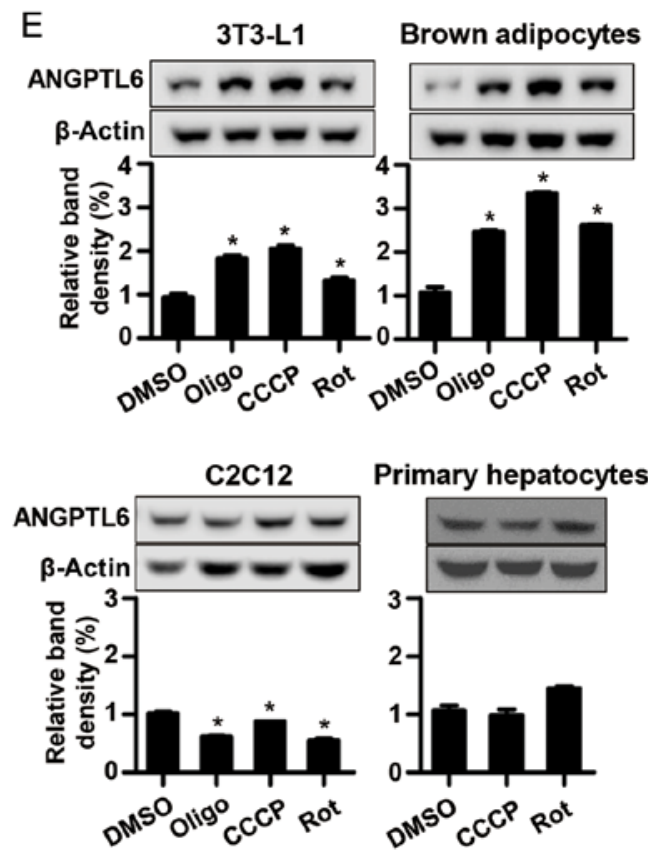

Figure 1

Reduced oxidative phosphorylation (OXPHOS) function induces angiopoietin-related growth factor (ANGPTL6) expression. (A) Comparison of gene sets encoding signaling proteins between heterozygous and homozygous Crif1-deficient mouse embryonic fibroblasts. (B) Normalized fold expression of angiopoietin-like proteins in microarray analysis. (C) Western blotting for ANGPTL6 and CRIF1 in heterozygous and homozygous Crif1-deficient mouse embryonic fibroblasts. (D) Real-time PCR analysis of 3T3-L1 adipocytes, mature immortalized brown adipocytes, C2C12 myoblasts and primary hepatocytes treated with vehicle or mitochondrial inhibitors. (E) Western blotting for ANGPTL6 expression in 3T3-L1 adipocytes, mature immortalized brown adipocytes, C2C12 myoblasts and primary hepatocytes treated with vehicle or mitochondrial inhibitors. All data are representative of three independent experiments. Data are expressed as mean \pm S.D. ${ }^{*} P<0.05, * * P<0.01$ vs the corresponding controls.

http://joe.endocrinology-journals.org DOI: 10.1530/JOE-16-0549
๑) 2017 Society for Endocrinology Printed in Great Britain
Published by Bioscientifica Ltd 
Table 2 Genes enriched in homozygous Crif1-/- MEFs.

\begin{tabular}{|c|c|c|c|}
\hline & Crif1+/- & Crif1-I- & Fold change \\
\hline Slamf6 & 8.03 & 416.84 & 51.89 \\
\hline NIrp4f & 16.48 & 772.06 & 46.84 \\
\hline s100a9 & 8.03 & 187.17 & 23.30 \\
\hline Hdgfl1 & 8.03 & 178.33 & 22.20 \\
\hline Tff3 & 24.65 & 470.75 & 19.10 \\
\hline Tenm1 & 13.17 & 221.48 & 16.82 \\
\hline Gstt4 & 55.78 & 831.12 & 14.90 \\
\hline Notch1 & 159.83 & 2340.52 & 14.64 \\
\hline Fgf21 & 29.62 & 400.90 & 13.53 \\
\hline Nrg2 & 174.46 & 1459.84 & 8.37 \\
\hline Gm5849 & 8.03 & 66.55 & 8.28 \\
\hline Dab1 & 9.43 & 76.46 & 8.11 \\
\hline Ly9 & 9.01 & 62.40 & 6.93 \\
\hline Siglecg & 57.95 & 366.19 & 6.32 \\
\hline Sema7a & 339.99 & 1978.86 & 5.82 \\
\hline Prl4a1 & 8.03 & 44.82 & 5.58 \\
\hline$A D M 2$ & 1074.60 & 5413.84 & 5.04 \\
\hline Lta & 44.83 & 219.50 & 4.90 \\
\hline Angptl6 & 6089.92 & 29012.53 & 4.76 \\
\hline Dab2ip & 116.27 & 546.43 & 4.70 \\
\hline Fli1 & 75.85 & 325.84 & 4.30 \\
\hline Sema4d & 518.69 & 2190.16 & 4.22 \\
\hline Tmprss9 & 27.93 & 114.32 & 4.09 \\
\hline
\end{tabular}

positive regulation of multicellular organismal processes and system development were enhanced in the Crif1-/MEFs compared to WT MEFs (Supplementary Fig. 1A, see section on supplementary data given at the end of this article). Interestingly, Angptl6 and Fgf21 were highly induced in homozygous Crif1-deficient MEFs (Fig. 1A and Table 2). By contrast, expression of other members of the ANGPTL family was not increased in Crif1-deficient MEFs (Fig. 1B). Moreover, the protein expression of ANGPTL6 was also enhanced in Crif1-deficient MEFs compared to that of control MEFs (Fig. 1C).

To extend our observation to adipocytes, we measured the expression of ANGPTL6 in adipocytes and nonadipocytes after inhibition of mitochondrial OXPHOS complex activity using oligomycin, CCCP and rotenone. As shown in Fig. 1D, E and Supplementary Fig. 1B, ANGPTL6 expression was significantly increased in 3T3L1 adipocytes and mature immortalized brown adipocytes treated with mitochondrial OXPHOS inhibitors, according to real-time PCR, Western blot analyses and ELISA. However, there was no correlation between mRNA and protein levels in the adipocytes treated with mitochondrial OXPHOS inhibitors. Treatment with oligomycin or rotenone increased the mRNA levels, but protein levels were actually reduced in C2C12 myoblasts (Fig. 1D and E). Discrepancies between proteomic and transcriptomic data were also seen in several previous investigations (Wang 2008, Maier et al. 2009). Moreover, in the previous report, these frequent discrepancies between variation in transcript and protein levels indicate that reanalysis of metabolic pathways using more comprehensive proteomic coverage may uncover unknown biological actions (Williams et al. 2016). In addition, differences between the associations at transcript and protein levels may indicate that post-transcriptional mechanisms might be important in the control of the protein expression. As no significant change in the expression of ANGPTL6 in primary hepatocytes was observed, this suggests that Angptl6 induction by treatment with mitochondrial inhibitors might be a cell type-specific phenomenon (Fig. 1D and E). We also investigated the expression of Angptl3 and Angptl4 in cultured adipocytes treated with vehicle, oligomycin, CCCP or rotenone. These chemicals increased the expression of Angptl6, but did not induce any changes in Angptl3 or Angptl4 expression in cultured adipocytes (Supplementary Fig. 1C). Furthermore, inhibitors such as rotenone and CCCP are known to induce ER stress. Therefore, we showed Angptl6 expression after treatment with doxycycline, which is more specific to mitochondria as a UPR'mt inducer. As expected, the expression of Angptl6 was enhanced in the cultured adipocytes treated with doxycycline (Supplementary Fig. 2A). However, we did not observe a significant increase in Angptl6 expression in cultured adipocytes treated with tunicamycin, which is an ER stress inducer (Supplementary Fig. 2B). Taken together, deficiency of CRIF1 or impaired OXPHOS function increased the expression of ANGPTL6 in cultured adipocytes.

\section{Development of adipose tissue-specific Crif1-deficient mice}

To confirm the in vivo effects of adipose OXPHOS reduction on ANGPTL6 expression, we generated adipocyte-specific Crif1-deficient mice (AdKO) by crossing Crif1flox/flox mice with Adiponectin-Cre transgenic mice (Ryu et al. 2013) (Fig. 2A). AdKO mice were born viable and did not show gross abnormalities until 8 weeks of development, but had larger brown adipose tissue depots (Fig. 2B). At 10 weeks of age, AdKO mice showed lower body weight gain than WT mice on a normal chow diet, but there was no significant difference in fasting blood glucose between the two groups (Fig. 2C). Epididymal white adipose tissue (eWAT) mass was reduced, whereas brown adipose tissue mass was increased in AdKO mice (Fig. 2D). As mitochondrial OXPHOS function is essential for maintaining thermogenesis in brown adipose tissue, the increased mass and discoloration may be a result of

Published by Bioscientifica Ltd 
A

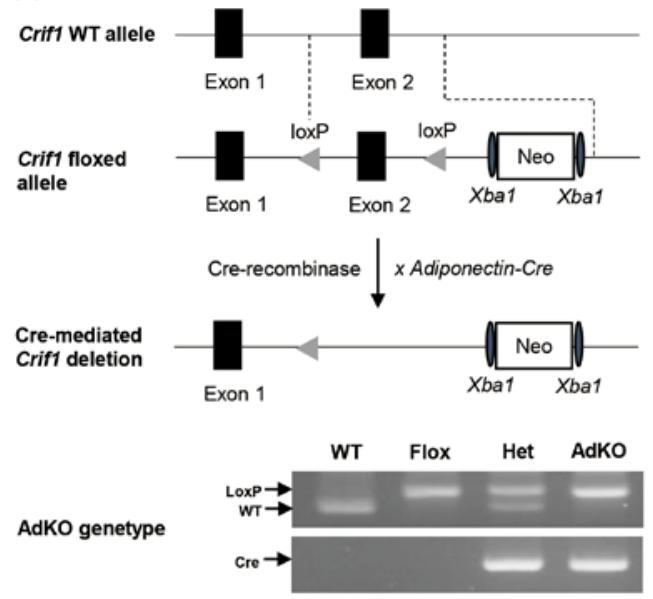

B

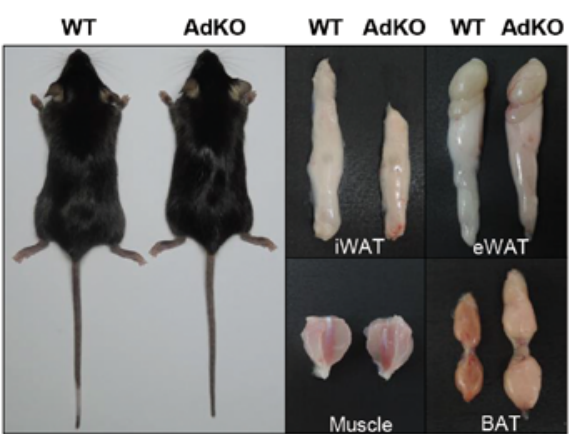

C
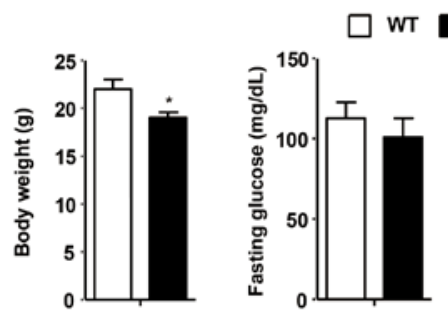

wT
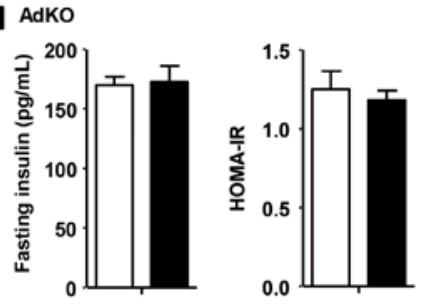

WT
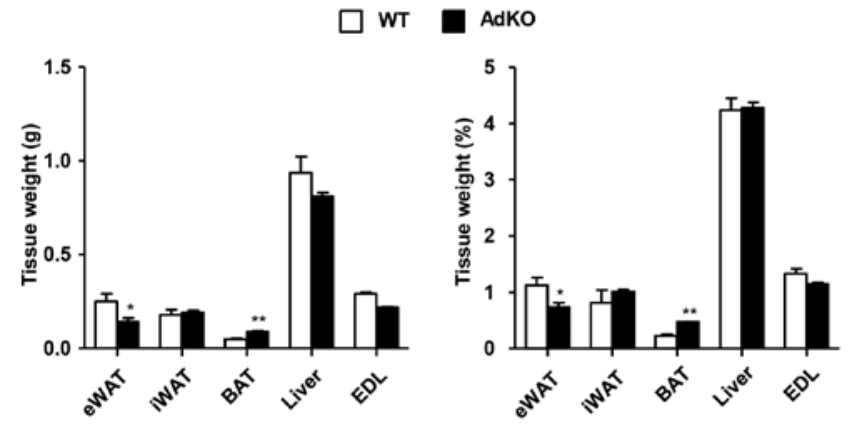

E
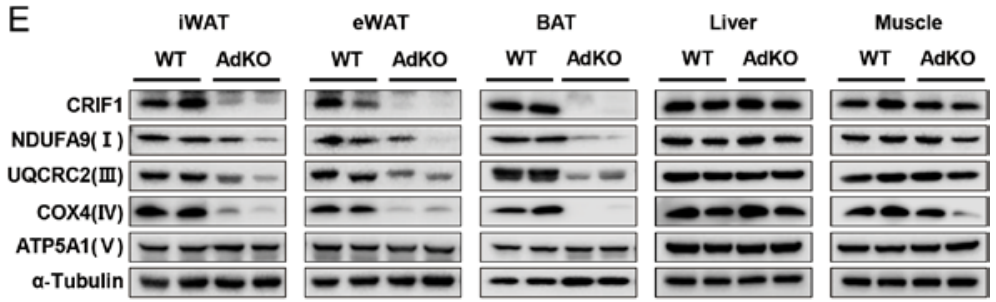

Figure 2

Development of adipose tissue-specific Crif1-deficient (AdKO) mice. (A) Strategy for generation of AdKO mice and genotype analysis using PCR.

(B) Gross appearance of control and AdKO mice (left) and images of white adipose tissue (right upper), muscle and brown adipose tissue (right lower) from control and AdKO male mice. (C) Measurement of body mass, fasting glucose, fasting insulin and HOMA-IR in WT and AdKO mice. (D) Comparison of tissue masses between WT and AdKO mice. (E) Western blotting for mitochondrial oxidative phosphorylation complex subunits in adipose tissue of control and AdKO mice at 8 weeks of age. The same blot was stripped and reprobed with the various antibodies. All data are representative of three independent experiments ( $n=5$ per group). Data are expressed as mean \pm S.D. ${ }^{*} P<0.05, * * P<0.01$ vs the corresponding controls.

decreased OXPHOS function. Consistent with this finding, a previous study also showed that lipolysis is important for the maintenance of a BAT phenotype (Ahmadian et al. 2011). On the other hand, we also observed a decrease in the size of WAT from AdKO mice compared to that in WT mice. We thought that this finding might be due to increased levels of FGF21, which is an inducer of lipolysis in WAT. Adipose tissue from AdKO mice displayed significantly reduced levels of OXPHOS subunits, including NDUFA9, UQCRC2 and COX IV, compared to that from the control group (Fig. 2E). Moreover, the expression of COX1, which is an mtDNA-encoded OXPHOS subunit, was also reduced in the WAT and brown adipose tissue, but not in the liver (Supplementary Fig. 3). These data suggest that Crif1 deficiency resulted in the decrease of OXPHOS subunits in adipose tissue and reduction in the mass of eWAT in mice.

\section{ANGPTL6 expression is increased in AdKO mice}

Emerging evidence suggests that reduced OXPHOS function in one organ can stimulate the activation of adaptive mitochondrial stress responses in other organs through non-cell-autonomous factors that are thought to be mitokines (Durieux et al. 2011, Houtkooper et al. 2013, Taylor et al. 2014). Although it is known that mitochondrial dysfunction induced by a deficiency in autophagy increases FGF21 expression (Kim et al. 2013), the identity of other secreted mediators and their interactions remain to be clarified. As shown in Fig. 1, ANGPTL6 expression was increased by the reduction in mitochondrial OXPHOS function in cultured adipocytes and MEFs. We also found that Angptl6 and Fgf21 expression was significantly increased in the white adipose tissue of AdKO mice (Fig. 3A). In Western blot

Published by Bioscientifica Ltd 
A
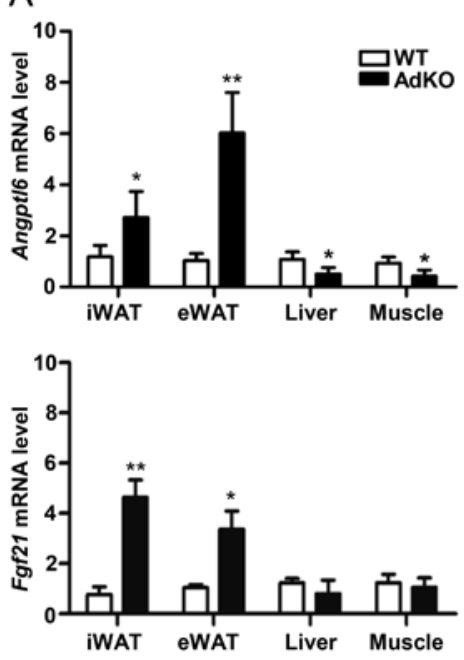

B
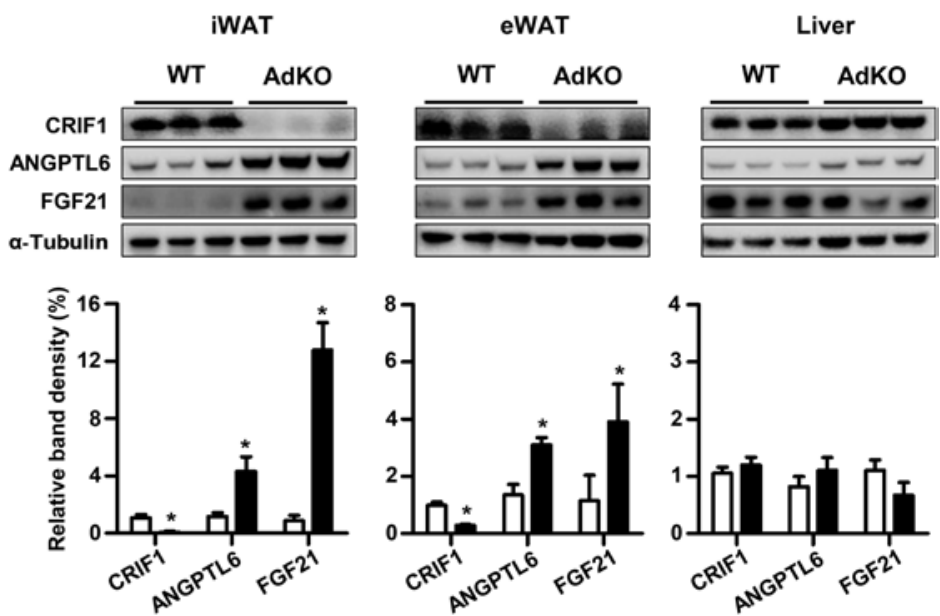

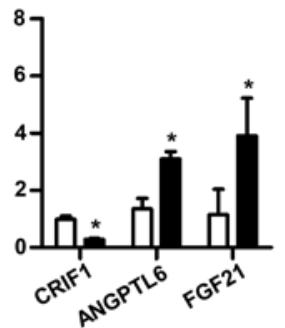

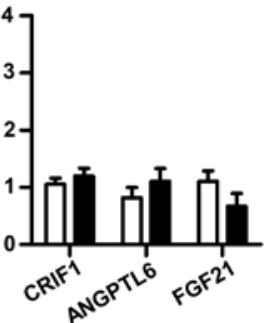
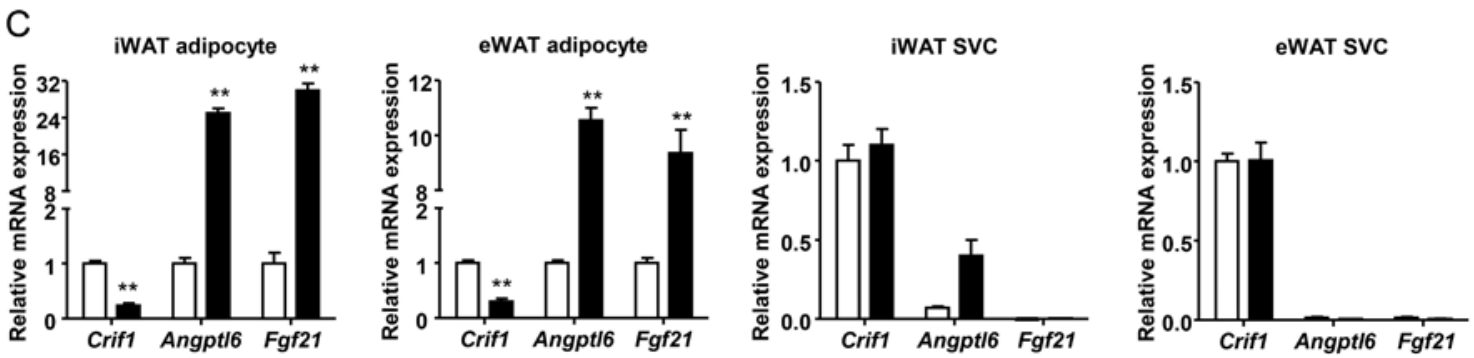

Figure 3

Angiopoietin-related growth factor (ANGPTL6) and fibroblast growth factor 21 (FGF21) expression in adipose tissue-specific Crif1-deficient (AdKO) mice. (A) Real-time PCR analysis of white adipose, liver and muscle RNA from control and male AdKO mice. (B) Immunoblotting for CRIF1, ANGPTL6 and FGF21 in white adipose tissue and liver of control and male AdKO mice. Relative quantification of each protein was undertaken using densitometry. The same blot was stripped and reprobed with the various antibodies. (C) Real-time PCR analysis of the adipocyte-enriched population and stromal vascular fraction from adipose tissue of WT and AdKO mice. All data are representative of three independent experiments ( $n=5$ per group). Data are expressed as mean \pm S.D. $* P<0.05, * * P<0.01$ vs the corresponding controls.

analysis, protein expression of ANGPTL6 and FGF21 was also higher in the white adipose tissue and brown adipose tissue of AdKO mice, but did not show any difference in the liver (Fig. 3B and Supplementary Fig. 4). Serum levels of FGF21 and Angptl6 were also increased in AdKO mice (Supplementary Fig. 5A and B). In addition, the adipose tissue concentration of FGF21 was also increased in AdKO mice compared to that in WT mice (Supplementary Fig. 5C). Moreover, epididymal and inguinal adipose (iWAT) depots were collected, digested and centrifuged to yield a buoyant adipocyte-enriched cell population and a pellet of SVCs. In real-time PCR analysis, Angptl6 and $F g f 21$ expression was significantly higher in the adipocyte-enriched cell population from the eWAT and iWAT of AdKO mice, whereas there was no significant difference from WT in expression in SVCs (Fig. 3C). Taken together, reduced mitochondrial OXPHOS function in adipose tissue increased the expression of ANGPTL6 and FGF21 in mice.

\section{ANGPTL6 increases Ppara expression by the regulation of ERK-MAPK pathways}

To determine the paracrine role of ANGPTL6, we observed the effects of ANGPTL6 on cellular mitochondrial function. The OCR was measured in 3T3-L1 adipocytes and primary hepatocytes treated with vehicle or recombinant murine ANGPTL6 protein (rANGPTL6). Treatment with rANGPTL6 increased the basal OCR and enhanced maximal OXPHOS capacity in 3T3-L1 adipocytes, but did not affect the OCR of primary hepatocytes (Fig. 4A and B). In addition, treatment with rANGPTL6 significantly increased the mRNA expression of Ppara, hormonesensitive lipase (Hsl), uncoupling protein 2 (Ucp2) and PPAR 
A

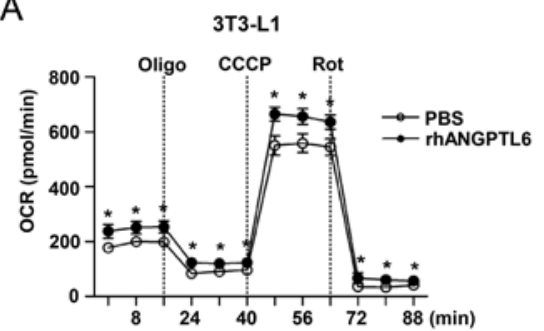

B

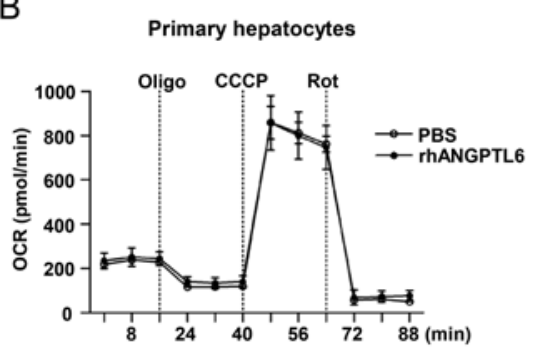

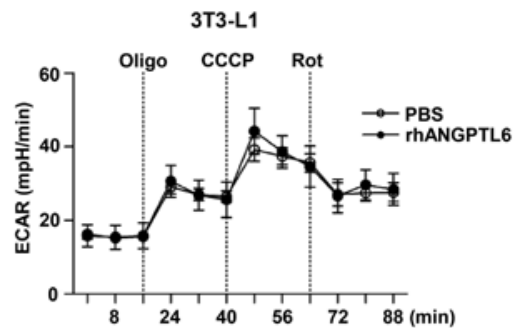

C

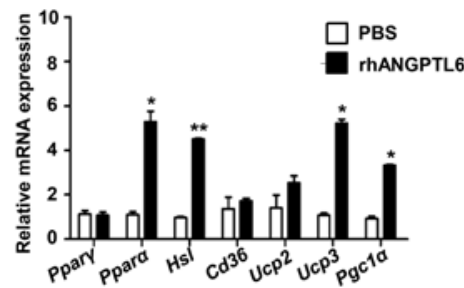

3T3-L1

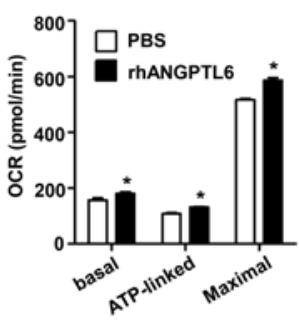

Brown adipocytes
D

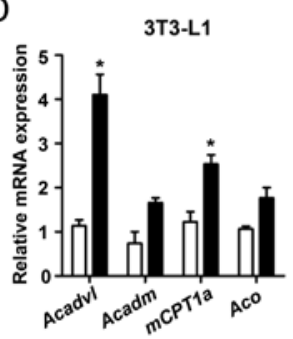

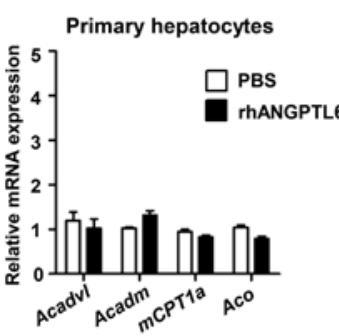

E
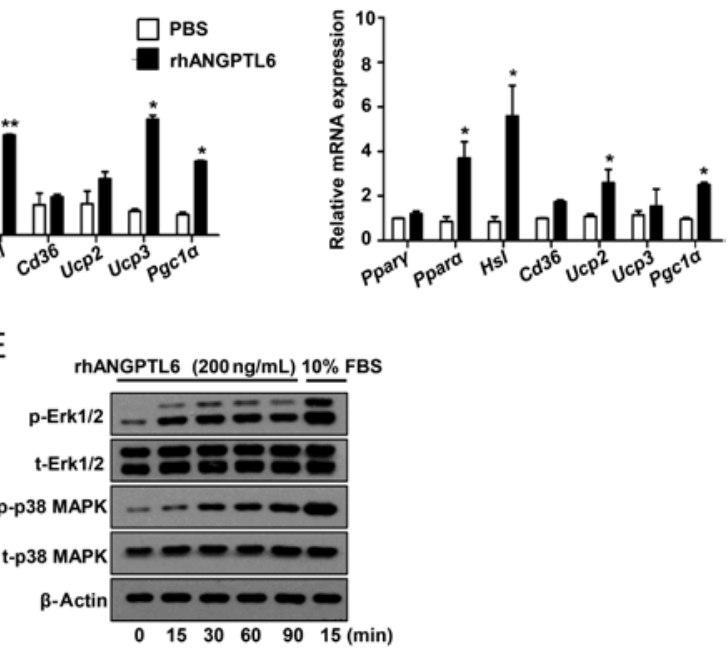

Figure 4

Angiopoietin-related growth factor (ANGPTL6) increases peroxisome proliferator-activated receptor- $\alpha$ (PPAR $\alpha$ ) expression by regulating the extracellular signal-regulated kinase (ERK)-mitogen-activated protein kinase (MAPK) pathway. (A and B) Oxygen consumption rates measured in 3T3-L1 adipocytes and primary cultured hepatocytes, respectively, \pm treatment with recombinant ANGPTL6 protein. (C and D) Real-time PCR analysis of RNA from 3T3-L1 adipocytes, mature immortalized brown adipocytes and primary hepatocytes treated with vehicle or recombinant ANGPTL6 protein. (E) Immunoblotting for ERK-MAPK signaling pathway components (phospho-ERK1/2, ERK1/2, phospho-p38 MAPK and p38 MAPK (Thr180/Tyr182)) in 3T3-L1 adipocytes treated with recombinant ANGPTL6 protein. All data are representative of three independent experiments ( $n=5$ per group). Data are expressed as mean \pm S.D. $* P<0.05, * * P<0.01$ vs the corresponding controls.

coactivator $1 \alpha(P G C-1 \alpha)$ in 3T3-L1 adipocytes and mature immortalized brown adipocytes (Fig. 4C). $\beta$-oxidationrelated genes were also upregulated in 3T3-L1 adipocytes and mature immortalized brown adipocytes treated with rANGPTL6, but this treatment did not affect their expression in primary hepatocytes (Fig. 4D).

A previous study demonstrated that p38 MAPK phosphorylates and activates the transcription factor PPAR $\alpha$ in cardiac myocytes (Barger et al. 2001). To reveal the mechanism of the increased PPAR $\alpha$ expression in rANGPTL6-treated 3T3-L1 adipocytes, we investigated the effect of ANGPTL6 on the ERK-MAPK pathway. Interestingly, treatment with rANGPTL6 dramatically increased the levels of phosphorylated ERK and p38 MAPK (Thr180/Tyr182) in 3T3-L1 adipocytes (Fig. 4E). Taken together, these data indicate that ANGPTL6 increased the expression of Ppara through activation of the ERKMAPK pathway.

\section{ANGPTL6 potentiates Ppar $\alpha$-mediated transcription of Fgf21}

The increased Ppar expression observed after treatment with rANGPTL6 suggested the possibility that FGF21 is regulated by ANGPTL6 in adipocytes (Badman et al. 2007, Inagaki et al. 2007). Thus, we investigated the effect of ANGPTL6 on FGF21 expression in cultured adipocytes. Real-time PCR analysis established that treatment with rANGPTL6 enhanced Fgf21 expression in 3T3-L1 adipocytes and mature immortalized brown adipocytes (Fig. 5A). Moreover, rANGPTL6 enhanced luciferase activity driven by the Ppara promoter in 3T3-L1 
A
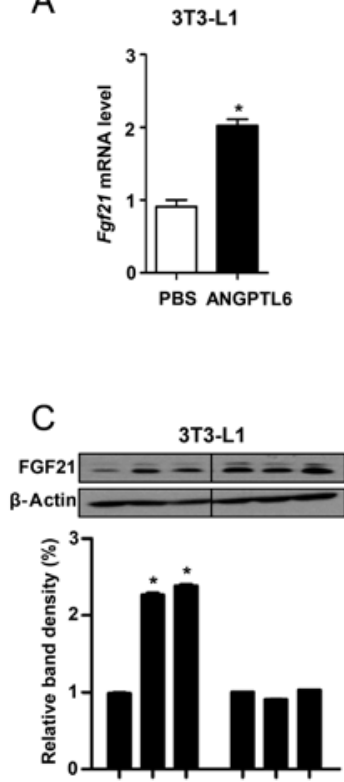

rANGPTL6: 02005000200500

B
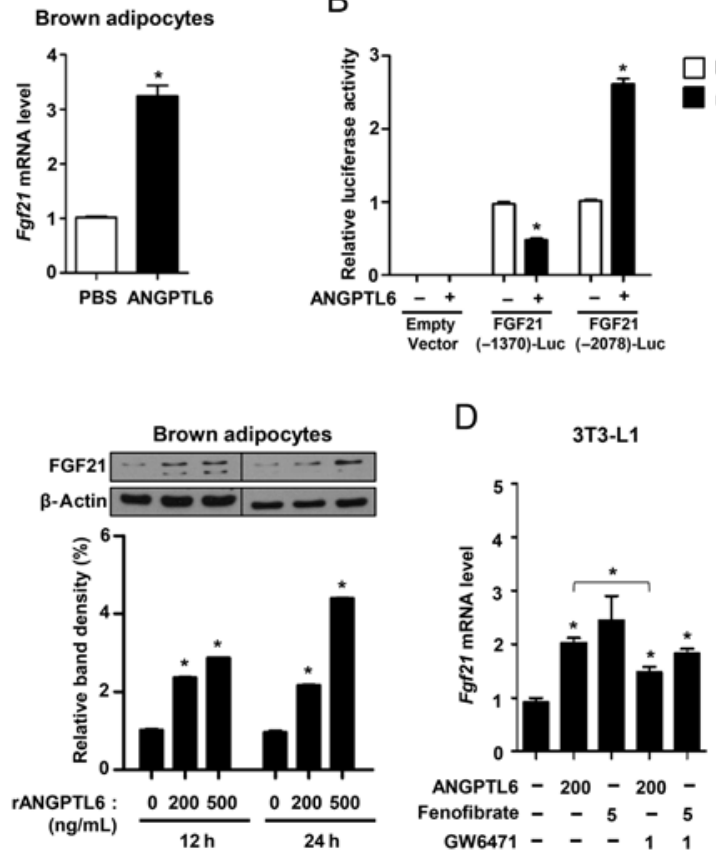

E Differentiated adipocytes

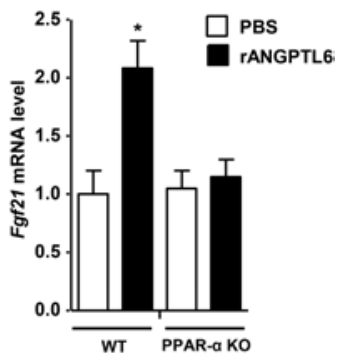

\section{Figure 5}

The angiopoietin-related growth factor (ANGPTL6)-induced increase in peroxisome proliferator-activated receptor- $\alpha$ (PPAR $\alpha$ ) results in increased fibroblast growth factor 21 (FGF21) expression. (A) Real-time PCR analysis of 3T3-L1 adipocytes and mature immortalized brown adipocytes treated with vehicle or recombinant ANGPTL6 protein. (B) Luciferase activity driven by the Ppar $\alpha$ promoter in 3T3-L1 adipocytes transfected with pGL3b-PPAR $\alpha$-Luc. (C) Western blotting for FGF21 in 3T3-L1 adipocytes treated with vehicle or recombinant ANGPTL6 protein. (D) Real-time PCR analysis of Fgf21 expression in 3T3-L1 adipocytes treated with recombinant ANGPTL6 protein, a PPAR $\alpha$ agonist, or a PPAR $\alpha$ antagonist. (E) Real-time PCR analysis of Fgf21 expression in WT and Ppar $\alpha$-deficient differentiated adipocytes treated with vehicle or recombinant ANGPTL6 protein. All data are representative of three independent experiments. Data are mean \pm S.D. ${ }^{*} P<0.05$ vs the corresponding controls.

adipocytes transfected with pGL3b-PPAR $\alpha$-Luc (Fig. 5B). FGF21 expression was also increased in 3T3-L1 adipocytes and brown adipocytes treated with rANGPTL6 (Fig. 5C). In contrast to brown adipocytes, FGF21 levels were increased at 12 , but not $24 \mathrm{~h}$ in 3T3-L1 adipocytes treated with rANGPTL6 (Fig. 5C). This discrepancy may be due to the normalized expression of recombinant ANGPTL6induced PPAR $\alpha$ in cultured adipocytes at the 24-h time point (Supplementary Fig. 6). To define the effect of PPAR $\alpha$ on FGF21 expression in 3T3-L1 adipocytes, we also investigated ANGPTL6-mediated Fgf21 expression using GW6471 as an inhibitor of PPAR $\alpha$ and fenofibrate as a PPAR $\alpha$ agonist. Interestingly, treatment with GW6471 significantly decreased ANGPTL6-mediated Fgf21 expression in 3T3-L1 adipocytes (Fig. 5D). Furthermore, treatment with rANGPTL6 increased Fgf21 expression in WT, but not Ppar $\alpha$-deficient, differentiated adipocytes (Fig. 5E). These observations demonstrated that PPAR $\alpha$ is essential for ANGPTL6-mediated FGF21 expression in cultured adipocytes. Taken together, these data demonstrate that expression of ANGPTL6 is coupled with reduced mitochondrial OXPHOS function, and its paracrine effects are characterized by enhanced mitochondrial oxidative function and stimulation of FGF21 expression in adipocytes.

\section{Discussion}

Mitochondria are crucial for cellular and systemic energy homeostasis in humans and rodents. The mitochondrial OXPHOS system, which is composed of five multimeric complexes embedded in the mitochondrial inner membrane, plays an important role in energy production and the generation of free radicals in cells. Recent studies in D. melanogaster and C. elegans revealed that mutation or reduced function of electron transport chain components increased longevity via activation of cell-autonomous and non-cell-autonomous factors (Durieux et al. 2011, Houtkooper et al. 2013). These studies suggested that reduced mitochondrial function induces a number of secreted factors. CRIF1 is known to interact with several nuclear receptors, including the nerve growth factor IB, androgen receptor, signal transducer and activator 
of transcription 3, E74-like factor 3 and NF-E2-related factor 2 , thereby regulating the function of these proteins and has been suggested to be a regulator of cell cycle progression and cell growth (Park et al. 2005, Kwon et al. 2008, 2009, Suh et al. 2008, Kang et al. 2010). CRIF1 is also important in mitochondria for the maintenance of OXPHOS function in vitro and in vivo (Kim et al. 2012). Therefore, we generated cellular and mouse models of reduced mitochondrial function (Crif1-deficient MEFs and AdKO mice, respectively) to clarify the effects of reduced OXPHOS function on the expression of secreted factors (Figs 1 and 2). We identified increased expression of ANGPTL6 in Crif1-deficient MEFs, as well as in white and brown adipose tissues from AdKO mice.

More recently, it was demonstrated that activation of mitochondrial stress responses is induced by specific conditions, including respiratory chain gene mutations (Baker et al. 2012, Nargund et al. 2012), imbalances between mtDNA-encoded and nuclear-encoded OXPHOS subunits (Houtkooper et al. 2013), inhibition of mitochondrial proteases, chaperones, respiratory chain complex assembly factors (Pulliam et al. 2014) and treatment with respiratory chain inhibitors (Nargund et al. 2012, Liu et al. 2014). In previous investigations, CRIF1 was identified as a mitoribosomal factor required for intramitochondrial production and insertion of OXPHOS polypeptides into the inner membrane (Kim et al. 2012, Greber et al. 2014). Therefore, the absence of Crif1 results in profound impairment of cellular respiration. In the current study, we clarified the effects of impaired mitochondrial OXPHOS function using Crif1-deficient MEFs and AdKO mice. Moreover, we suggest that ANGPTL6 is a non-cellautonomous factor induced by the reduction in OXPHOS function in 3T3-L1 adipocytes and adipose tissue from AdKO mice. Based on our observations, mitochondrial function in white adipose tissue may be regulated not only through cell-autonomous mechanisms but also through non-cell-autonomous effects, thereby regulating local and systemic energy homeostasis by paracrine and endocrine mechanisms.

ANGPTL6, also known as AGF, was identified as an orphan peptide containing an N-terminal coiled-coil domain and a C-terminal fibrinogen-like domain, which does not bind to the angiopoietin receptor (Oike et al. 2003). ANGPTL6 was initially described as a secreted angiogenic factor involved in promoting angiogenesis and cutaneous wound healing (Oike et al. 2003, 2004). However, recent emerging evidence suggests that ANGPTL6 has biological functions in non-vascular cells. For example, disruption of Angptl6 in mice leads to marked obesity and lipid accumulation in skeletal muscle and liver, thereby producing insulin resistance, accompanied by decreased energy expenditure (Oike et al. 2005). However, Angptl6-transgenic mice were resistant to obesity, insulin resistance and non-adipose tissue steatosis (Oike et al. 2005). Furthermore, serum ANGPTL6 was significantly increased in patients with type 2 diabetes compared with that in non-diabetic controls and positively correlated with fasting blood glucose, independent of age, sex, body mass index and glomerular filtration rate (Ebert et al. 2009, Namkung et al. 2011). However, little is known about the mechanism of action or the physiological relevance of ANGPTL6 in adipose tissue because its cognate receptor has not been identified.

ANGPTL6 was previously reported to be an angiogenic and liver-derived secreted factor. In the present study, we observed ANGPTL6 expression at both the RNA and protein levels in adipose tissue and 3T3-L1 adipocytes, suggesting that ANGPTL6 may also be secreted from adipose tissue. Moreover, this study showed that reduced OXPHOS function in adipose tissue results in increased production of ANGPTL6, which promotes the gene expression of $\beta$-oxidation enzymes in cultured adipocytes. ANGPTL6 also suppresses glucose production through AKT/forkhead box class O1-dependent signaling in hepatocytes (Kitazawa et al. 2007). Treatment with rANGPTL6 increased adenosine monophosphate-activated protein kinase (AMPK) activity, thereby improving insulin signaling in the skeletal muscle of diet-induced obese mice (Hato et al. 2008). Furthermore, ANGPTL6 enhances the ligand-binding activities of PPAR $\alpha$ and PPAR $\delta$ in C2C12 myoblasts and activates p38 MAPK in skeletal muscles (Oike et al. 2005). Taken together, these findings demonstrate that ANGPTL6 is closely associated with enhanced systemic energy expenditure.

Notably, Angptl6 expression was markedly increased in Crif1-deficient MEFs and 3T3-L1 adipocytes treated with inhibitors of the mitochondrial OXPHOS complex. In parallel, AdKO mice displayed significant increases in ANGPTL6 expression in both visceral and subcutaneous adipose tissue. Moreover, ANGPTL6 modulated PPAR $\alpha$ expression and $\beta$-oxidation via the ERK-MAPK pathway in 3T3-L1 adipocytes. Collectively, these findings provide evidence for the non-cell-autonomous factor ANGPTL6 as a regulator of FGF21 production in cultured adipocytes and AdKO mice.

Emerging evidence shows that FGF21 is involved in mitochondrial dysfunction and diseases in human patients. Serum FGF21 increased in patients with mitochondrial translation defects or mitochondrial DNA

Published by Bioscientifica Ltd 
deletions (Lehtonen et al. 2016). FGF21 secretion by muscle cells with mitochondrial alterations may be an adaptive physiological mechanism to regulate systemic energy metabolism (Ribas et al. 2014). In the current study, we also observed increased levels of FGF21 in adipose tissue and the serum of mice with adipose tissuespecific mitochondrial OXPHOS dysfunction. This finding suggests that serum levels of FGF21 can be increased by mitochondrial dysfunction in adipose tissue as well as in skeletal muscle.

PPAR $\alpha$ is a critical transcription factor that is regulated as part of metabolic stress responses under both physiologic and pathologic conditions. In the current study, we showed that ANGPTL6 increased the expression of Ppara via activation of the ERK-MAPK signaling pathway in 3T3-L1 adipocytes (Fig. 3). In line with our findings, p38 MAPK also phosphorylates and activates PPAR $\alpha$, leading to an increase in the ligand-mediated transactivation of targets and enhanced cooperation with the transcriptional coactivator PGC-1 in cardiac myocytes (Barger et al. 2001). Moreover, the p38 MAPK signaling pathway is involved in the adiponectin-mediated activation and transcriptional activity of PPAR $\alpha$ in C2C12 myoblasts (Yoon et al. 2006), whereas insulin-induced activation of PPAR $\alpha$ is mediated via the ERK-MAPK pathway in hepatocytes (Shalev et al. 1996). By contrast, ERK-MAPK signaling is known to reduce PPAR $\alpha$ activity and induce gene expression in hypertrophied cardiac myocytes (Barger et al. 2000). The detailed molecular mechanism underlying this discrepancy has not been established, but the context-specific nature of nuclear receptor phosphorylation is likely of importance. Thus, further studies are needed to determine the effects of MAPK activation on PPAR $\alpha$ activity and expression under diverse conditions.

In summary, inhibition of mitochondrial OXPHOS function-mediated ANGPTL6 production increases the expression of Ppara via the activation of the ERK-MAPK signaling pathway in 3T3-L1 adipocytes and the adipose tissue of AdKO mice. Therefore, this study suggests that mitochondrial OXPHOS function influences the expression of non-cell-autonomous factors in adipose tissue, and therefore represents a novel regulator of fat metabolism.

\section{Supplementary data}

This is linked to the online version of the paper at http://dx.doi.org/10.1530/ JOE-16-0549.
Declaration of interest

The authors declare that there is no conflict of interest that could be perceived as prejudicing the impartiality of the research reported.

\section{Funding}

This work was supported by the Basic Science Research Program, through the National Research Foundation of Korea (NRF), funded by the Ministry of Science, ICT, and Future Planning, Korea (NRF-2015R1A2A1A13000951). H W K was supported by grants from the NRF, funded by the Ministry of Science, ICT, and Future Planning (no. NRF-2015R1A5A1009024). H S Y was supported by the Basic Science Research Program, through the NRF, funded by the Ministry of Science, ICT, and Future Planning, Korea (NRF-2015R1C1A1A01052432). J H L was supported by the Basic Science Research Program through the NRF, funded by the Ministry of Science, ICT, and Future Planning, Korea (NRF-2014R1A1A1006176). S G K and M J C were supported by the NRF, funded by the Ministry of Science, ICT, and Future Planning (no. 2012M3A9B2027958).

\section{References}

Ahmadian M, Abbott MJ, Tang T, Hudak CS, Kim Y, Bruss M, Hellerstein MK, Lee HY, Samuel VT, Shulman GI, et al. 2011 Desnutrin/ATGL is regulated by AMPK and is required for a brown adipose phenotype. Cell Metabolism 13 739-748. (doi:10.1016/j. cmet.2011.05.002)

Badman MK, Pissios P, Kennedy AR, Koukos G, Flier JS \& Maratos-Flier E 2007 Hepatic fibroblast growth factor 21 is regulated by PPARalpha and is a key mediator of hepatic lipid metabolism in ketotic states. Cell Metabolism 5 426-437. (doi:10.1016/j.cmet.2007.05.002)

Baker BM, Nargund AM, Sun T \& Haynes CM 2012 Protective coupling of mitochondrial function and protein synthesis via the eIF2alpha kinase GCN-2. PLoS Genetics 8 e1002760. (doi:10.1371/journal. pgen.1002760)

Barger PM, Brandt JM, Leone TC, Weinheimer CJ \& Kelly DP 2000 Deactivation of peroxisome proliferator-activated receptor-alpha during cardiac hypertrophic growth. Journal of Clinical Investigation 105 1723-1730. (doi:10.1172/JCI9056)

Barger PM, Browning AC, Garner AN \& Kelly DP 2001 p38 mitogenactivated protein kinase activates peroxisome proliferatoractivated receptor alpha: a potential role in the cardiac metabolic stress response. Journal of Biological Chemistry 276 44495-44501. (doi:10.1074/jbc.M105945200)

Byun J, Son SM, Cha MY, Shong M, Hwang YJ, Kim Y, Ryu H, Moon M, Kim KS \& Mook-Jung I 2015 CR6-interacting factor 1 is a key regulator in Abeta-induced mitochondrial disruption and pathogenesis of Alzheimer's disease. Cell Death and Differentiation 22 959-973. (doi:10.1038/cdd.2014.184)

Copeland JM, Cho J, Lo T Jr, Hur JH, Bahadorani S, Arabyan T, Rabie J, Soh J \& Walker DW 2009 Extension of Drosophila life span by RNAi of the mitochondrial respiratory chain. Current Biology 19 1591-1598. (doi:10.1016/j.cub.2009.08.016)

Dillin A, Hsu AL, Arantes-Oliveira N, Lehrer-Graiwer J, Hsin H, Fraser AG, Kamath RS, Ahringer J \& Kenyon C 2002 Rates of behavior and aging specified by mitochondrial function during development. Science 298 2398-2401. (doi:10.1126/science.1077780)

Durieux J, Wolff S \& Dillin A 2011 The cell-non-autonomous nature of electron transport chain-mediated longevity. Cell 144 79-91. (doi:10.1016/j.cell.2010.12.016)

Ebert T, Bachmann A, Lossner U, Kratzsch J, Bluher M, Stumvoll M \& Fasshauer M 2009 Serum levels of angiopoietin-related growth http://joe.endocrinology-journals.org

DOI: $10.1530 / \mathrm{JOE}-16-0549$
() 2017 Society for Endocrinology Printed in Great Britain
Published by Bioscientifica Ltd 
factor in diabetes mellitus and chronic hemodialysis. Metabolism $\mathbf{5 8}$ 547-551. (doi:10.1016/j.metabol.2008.11.016)

Greber BJ, Boehringer D, Leibundgut M, Bieri P, Leitner A, Schmitz N, Aebersold R \& Ban N 2014 The complete structure of the large subunit of the mammalian mitochondrial ribosome. Nature $\mathbf{5 1 5}$ 283-286. (doi:10.1038/nature13895)

Hato T, Tabata M \& Oike Y 2008 The role of angiopoietin-like proteins in angiogenesis and metabolism. Trends in Cardiovascular Medicine 18 6-14. (doi:10.1016/j.tcm.2007.10.003)

Hotta Y, Nakamura H, Konishi M, Murata Y, Takagi H, Matsumura S, Inoue K, Fushiki T \& Itoh N 2009 Fibroblast growth factor 21 regulates lipolysis in white adipose tissue but is not required for ketogenesis and triglyceride clearance in liver. Endocrinology 150 4625-4633. (doi:10.1210/en.2009-0119)

Houtkooper RH, Mouchiroud L, Ryu D, Moullan N, Katsyuba E, Knott G, Williams RW \& Auwerx J 2013 Mitonuclear protein imbalance as a conserved longevity mechanism. Nature 497 451-457. (doi:10.1038/ nature12188)

Inagaki T, Dutchak P, Zhao G, Ding X, Gautron L, Parameswara V, Li Y, Goetz R, Mohammadi M, Esser V, et al. 2007 Endocrine regulation of the fasting response by PPARalpha-mediated induction of fibroblast growth factor 21. Cell Metabolism 5 415-425. (doi:10.1016/j. cmet.2007.05.003)

Kaaman M, Sparks LM, van Harmelen V, Smith SR, Sjolin E, Dahlman I \& Arner P 2007 Strong association between mitochondrial DNA copy number and lipogenesis in human white adipose tissue. Diabetologia 50 2526-2533. (doi:10.1007/s00125-007-0818-6)

Kang HJ, Hong YB, Kim HJ \& Bae I 2010 CR6-interacting factor 1 (CRIF1) regulates NF-E2-related factor 2 (NRF2) protein stability by proteasome-mediated degradation. Journal of Biological Chemistry $\mathbf{2 8 5}$ 21258-21268. (doi:10.1074/jbc.M109.084590)

Kim SJ, Kwon MC, Ryu MJ, Chung HK, Tadi S, Kim YK, Kim JM, Lee SH, Park JH, Kweon GR, et al. 2012 CRIF1 is essential for the synthesis and insertion of oxidative phosphorylation polypeptides in the mammalian mitochondrial membrane. Cell Metabolism 16 274-283. (doi:10.1016/j.cmet.2012.06.012)

Kim KH, Jeong YT, Oh H, Kim SH, Cho JM, Kim YN, Kim SS, Kim do H, Hur KY, Kim HK, et al. 2013 Autophagy deficiency leads to protection from obesity and insulin resistance by inducing Fgf21 as a mitokine. Nature Medicine 19 83-92. (doi:10.1038/nm.3014)

Kim YK, Joung KH, Ryu MJ, Kim SJ, Kim H, Chung HK, Lee MH, Lee SE, Choi MJ, Chang JY, et al. 2015 Disruption of CR6-interacting factor-1 (CRIF1) in mouse islet beta cells leads to mitochondrial diabetes with progressive beta cell failure. Diabetologia 58 771-780. (doi:10.1007/ s00125-015-3506-y)

Kitazawa M, Ohizumi Y, Oike Y, Hishinuma T \& Hashimoto S 2007 Angiopoietin-related growth factor suppresses gluconeogenesis through the Akt/forkhead box class O1-dependent pathway in hepatocytes. Journal of Pharmacology and Experimental Therapeutics $\mathbf{3 2 3}$ 787-793. (doi:10.1124/jpet.107.127530)

Kwon MC, Koo BK, Moon JS, Kim YY, Park KC, Kim NS, Kwon MY, Kong MP, Yoon KJ, Im SK, et al. 2008 Crif1 is a novel transcriptional coactivator of STAT3. EMBO Journal 27 642-653. (doi:10.1038/ sj.emboj.7601986)

Kwon MC, Koo BK, Kim YY, Lee SH, Kim NS, Kim JH \& Kong YY 2009 Essential role of CR6-interacting factor 1 (Crif1) in E74-like factor 3 (ELF3)-mediated intestinal development. Journal of Biological Chemistry 284 33634-33641. (doi:10.1074/jbc.M109.059840)

Lehtonen JM, Forsstrom S, Bottani E, Viscomi C, Baris OR, Isoniemi H, Hockerstedt K, Osterlund P, Hurme M, Jylhava J, et al. 2016 FGF21 is a biomarker for mitochondrial translation and mtDNA maintenance disorders. Neurology 87 2290-2299. (doi:10.1212/ WNL.0000000000003374)

Liu X, Jiang N, Hughes B, Bigras E, Shoubridge E \& Hekimi S 2005 Evolutionary conservation of the clk-1-dependent mechanism of longevity: loss of mclk1 increases cellular fitness and lifespan in mice. Genes and Development 19 2424-2434. (doi:10.1101/gad.1352905)

Liu Y, Samuel BS, Breen PC \& Ruvkun G 2014 Caenorhabditis elegans pathways that surveil and defend mitochondria. Nature 508 406-410. (doi:10.1038/nature13204)

Maier T, Guell M \& Serrano L 2009 Correlation of mRNA and protein in complex biological samples. FEBS Letters 583 3966-3973. (doi:10.1016/j.febslet.2009.10.036)

Namkung J, Koh SB, Kong ID, Choi JW \& Yeh BI 2011 Serum levels of angiopoietin-related growth factor are increased in metabolic syndrome. Metabolism 60 564-568. (doi:10.1016/j. metabol.2010.05.013)

Nargund AM, Pellegrino MW, Fiorese CJ, Baker BM \& Haynes CM 2012 Mitochondrial import efficiency of ATFS-1 regulates mitochondrial UPR activation. Science 337 587-590. (doi:10.1126/science.1223560)

Oike Y, Yasunaga K, Ito Y, Matsumoto S, Maekawa H, Morisada T, Arai F, Nakagata N, Takeya M, Masuho Y, et al. 2003 Angiopoietinrelated growth factor (AGF) promotes epidermal proliferation, remodeling, and regeneration. PNAS 100 9494-9499. (doi:10.1073/ pnas.1531901100)

Oike Y, Ito Y, Maekawa H, Morisada T, Kubota Y, Akao M, Urano T, Yasunaga K \& Suda T 2004 Angiopoietin-related growth factor (AGF) promotes angiogenesis. Blood 103 3760-3765. (doi:10.1182/blood2003-04-1272)

Oike Y, Akao M, Yasunaga K, Yamauchi T, Morisada T, Ito Y, Urano T, Kimura Y, Kubota Y, Maekawa H, et al. 2005 Angiopoietin-related growth factor antagonizes obesity and insulin resistance. Nature Medicine 11 400-408. (doi:10.1038/nm1214)

Park KC, Song KH, Chung HK, Kim H, Kim DW, Song JH, Hwang ES, Jung HS, Park SH, Bae I, et al. 2005 CR6-interacting factor 1 interacts with orphan nuclear receptor Nur77 and inhibits its transactivation. Molecular Endocrinology 19 12-24. (doi:10.1210/me.2004-0107)

Pulliam DA, Deepa SS, Liu Y, Hill S, Lin AL, Bhattacharya A, Shi Y, Sloane L, Viscomi C, Zeviani M, et al. 2014 Complex IV-deficient Surf1(-/-) mice initiate mitochondrial stress responses. Biochemical Journal 462 359-371. (doi:10.1042/BJ20140291)

Ribas F, Villarroya J, Hondares E, Giralt M \& Villarroya F 2014 FGF21 expression and release in muscle cells: involvement of MyoD and regulation by mitochondria-driven signalling. Biochemical Journal 463 191-199. (doi:10.1042/BJ20140403)

Rong JX, Qiu Y, Hansen MK, Zhu L, Zhang V, Xie M, Okamoto Y, Mattie MD, Higashiyama H, Asano S, et al. 2007 Adipose mitochondrial biogenesis is suppressed in $\mathrm{db} / \mathrm{db}$ and high-fat dietfed mice and improved by rosiglitazone. Diabetes 56 1751-1760. (doi:10.2337/db06-1135)

Ryu MJ, Kim SJ, Kim YK, Choi MJ, Tadi S, Lee MH, Lee SE, Chung HK, Jung SB, Kim HJ, et al. 2013 Crif1 deficiency reduces adipose OXPHOS capacity and triggers inflammation and insulin resistance in mice. PLoS Genetics 9 e1003356. (doi:10.1371/journal.pgen.1003356)

Shalev A, Siegrist-Kaiser CA, Yen PM, Wahli W, Burger AG, Chin WW $\&$ Meier CA 1996 The peroxisome proliferator-activated receptor alpha is a phosphoprotein: regulation by insulin. Endocrinology 137 4499-4502. (doi:10.1210/en.137.10.4499)

Suh JH, Shong M, Choi HS \& Lee K 2008 CR6-interacting factor 1 represses the transactivation of androgen receptor by direct interaction. Molecular Endocrinology 22 33-46. (doi:10.1210/me.20070194)

Taylor RC, Berendzen KM \& Dillin A 2014 Systemic stress signalling: understanding the cell non-autonomous control of proteostasis. Nature Reviews Molecular Cell Biology 15 211-217. (doi:10.1038/nrm3752)

Vernochet C, Mourier A, Bezy O, Macotela Y, Boucher J, Rardin MJ, An D, Lee KY, Ilkayeva OR, Zingaretti CM, et al. 2012 Adipose-specific deletion of TFAM increases mitochondrial oxidation and protects mice against obesity and insulin resistance. Cell Metabolism 16 765-776. (doi:10.1016/j.cmet.2012.10.016)
๑ 2017 Society for Endocrinology Printed in Great Britain 
Wang D 2008 Discrepancy between mRNA and protein abundance: insight from information retrieval process in computers. Computational Biology and Chemistry 32 462-468. (doi:10.1016/j. compbiolchem.2008.07.014)

Williams EG, Wu Y, Jha P, Dubuis S, Blattmann P, Argmann CA, Houten SM, Amariuta T, Wolski W, Zamboni N, et al. 2016 Systems proteomics of liver mitochondria function. Science $\mathbf{3 5 2}$ aad0189. (doi:10.1126/science.aad0189)

Wilson-Fritch L, Nicoloro S, Chouinard M, Lazar MA, Chui PC, Leszyk J, Straubhaar J, Czech MP \& Corvera S 2004 Mitochondrial remodeling in adipose tissue associated with obesity and treatment with rosiglitazone. Journal of Clinical Investigation 114 1281-1289. (doi:10.1172/JCI21752)

Yi HS, Lee YS, Byun JS, Seo W, Jeong JM, Park O, Duester G, Haseba T, Kim SC, Park KG, et al. 2014 Alcohol dehydrogenase III exacerbates liver fibrosis by enhancing stellate cell activation and suppressing natural killer cells in mice. Hepatology 60 1044-1053. (doi:10.1002/hep.27137) Yoon MJ, Lee GY, Chung JJ, Ahn YH, Hong SH \& Kim JB 2006 Adiponectin increases fatty acid oxidation in skeletal muscle cells by sequential activation of AMP-activated protein kinase, p38 mitogenactivated protein kinase, and peroxisome proliferator-activated receptor alpha. Diabetes 55 2562-2570. (doi:10.2337/db05-1322)

Received in final form 31 January 2017

Accepted 9 February 2017

Accepted Preprint published online 9 February 2017
Published by Bioscientifica Ltd. 